\title{
MODERATE INTENSITY EXERCISE EFFECT REPRODUCTIVE CYCLE ON HIGH CALORIES DIET IN MICE (MUS MUSCULUS)
}

\author{
Gebyar Catur Wahyuning $\mathbf{R}^{\mathbf{1}}$, Lilik Herawati ${ }^{2}$, Siti Khaerunisa ${ }^{3}$, \\ Astika Gita Ningrum ${ }^{4}$ \\ Universitas Airlangga ${ }^{1,2,3,4}$ \\ astika.gita.n@fk.unair.ac.id
}

\begin{abstract}
Excessive glucose intake can lead to fat accumulation which can increase the aromatization of androgens to estrogen levels. High estrogen levels can disturb GnRH secretion feedback, prolonging the reproductive cycle, and affecting the uterine. As a condition, it is essential to encourage moderate exercise to reduce fat accumulation and restore GnRH function. Good physical exercise has sufficient rest duration so that the required intensity, frequency, and time are right. This study aims to see how glucose intake affects the body and uterine weight with or without moderate exercise. This research was an experimental study. Healthy female mice, divided into 3 groups, negative control, high-calorie diet, and high-calorie diet with moderate exercise. A highcalorie diet was given by using sonde dextrose $40 \%$ as much as 0,325 ml/g Body Weight. Moderate exercise was swimming with a load of $6 \%$ BW. Mice were swum together 3 times a week for 4 weeks. The duration of the first week of swimming was 5 minutes, the second week was 7 minutes, the third week was 11 minutes and the fourth week was 15 minutes. The result of this research was the uterus weight $(p=0,051)$ did not show a significant difference between groups. However, uterus weight in the high-calorie diet group was higher $(0,19 \mathrm{gr})$ than a high-calorie diet with a moderate exercise group $(0,14$ $g r)$ and negative control group $(0,11 \mathrm{~g})$. The vagina swab result $(p=0,045)$ that there was a significant relationship between groups. Therefore, glucose intake with or without moderate exercise affects the reproductive cycle but did not affect uterine weight.
\end{abstract}

Keywords: Glucose intake; moderate exercise; nutrition risk; reproductive health; health risk.

Accepted: $17^{\text {th }}$ of January 2022

Correspondence author: Astika Gita Ningrum, Universitas Airlangga, Indonesia. E-Mail: astika.gita.n@fk.unair.ac.id

DOI http://dx.doi.org/10.31851/hon.v5i1.6328 d

\section{(c) (i) (2)}

Jurnal Halaman Olahraga Nusantara licensed under a Creative Commons Attribution-ShareAlike 4.0 International License

\section{INTRODUCTION}

Eating a variety of foods can be an important part of maintaining a healthy body. However, there are several food groups that can have a negative impact on reproductive health, one of which is increasing body weight. Increased weight can 
be caused by excessive calorie consumption, so there is a risk of obesity, diabetes mellitus and fertility problems. Based on (Kemenkes RI, 2018) the prevalence of obesity in Indonesia is around $13.6 \%$ of adults aged $>18$ years who are overweight and $21.8 \%$ are obesity. One of the impacting factors is a person's habit of eating high-fat, high-sugar, and other unhealthy foods (Kementerian Kesehatan RI, 2018). Being overweight in women can induce menstrual abnormalities due to high levels of estrogen from fat storage, which can interfere with feedback on GnRH production, therefore prolonging the menstrual cycle (Yuli Trisnawati, 2018). According to (Sunarsih, 2017) research, 31 (67.4\%) of 42 respondents with an high BMI reported irregular menstrual cycle. it consistent with study by (Dars et al., 2014) stated that $75,51 \%$ adolescents with a normal BMI or $14-24.9 \mathrm{~kg} / \mathrm{m}^{2}$ had regular menstrual and 16 adolescents with BMI 25-29,9 $\mathrm{kg} / \mathrm{m}^{2}$ have an irregular menstrual cycle. Weight gain can also disrupt the balance of steroid hormones such as androgens, estrogens, and steroid hormone binding globulin (SHBG). A study by (Akin et al., 2008), reported that there was a decrease in SHBG with an increase in Body Mass index (BMI). Changes in SHBG itself can cause changes in the release of androgens and estrogens in target tissues.

Therefore, an efficient method is needed to reduce the risk of increasing BMI, one of which is physical exercise. Physical exercise can control hypertension, diabetes, dyslipidemia, obesity and insulin resistance (Yang, 2019). However, the effect of moderate exercise as a preventive strategy on uterine weight and reproduction cycle in subject with high calorie diet is unknown. Therefore, this study is proposed to analyze the effect of moderate exercise on uterine weight and reproductive cycle on subject with high calorie diet as on parameters of the female reproductive function.

\section{METHOD}

This research is experimental laboratory with randomized posttest only control group design. The sampling technique used is probability sampling with simple random sampling. Subject in this study were healthy female mice (Mus 
Musculus). The number of samples used is at least six. The independent variables are moderate exercise and high calorie diet. The dependent variables are uterine weight and reproductive cycle. The research process was carried out at the Faculty of Veterinary Medicine, Universitas Airlangga, Surabaya. Mice were randomly divided into 3 groups, namely the control group (K1), the high calorie diet group (K2) and the high calorie diet with moderate exercise (K4). Each group contains a minimum of six mice. The control group was given a standart diet. The high calorie diet was given using $40 \%$ dextrose sonde of $0,325 \mathrm{ml} / \mathrm{g} \mathrm{BW}$ (Herawati et al., 2020). Moderate exercise in the form of swimming was given a load of $6 \%$ of the total body weight (Prasetya et al., 2018). The duration of swimming process in the first week was around 5 minutes, the second week for 7 minutes, the third week for 11 minutes, and the fourth week for 15 minutes.

After 4 weeks of treat, a vaginal swab and surgery were performed at the Faculty of Veterinary Medicine, Universitas Airlangga to take the uterine organs. The data analysis in this study namely, descriptive, normality test use Shapirowilk, homogenous test use Levene's test. The data has been collected is processed by the robust test because the data is not homogenous and by fisher test to determine wheter the two variables are related. This research has received ethical approval from the Health research Ethics Committee, Faculty of Medicine, Universitas Airlangga No. 78/EC/KEPK/FKUA/2021.

\section{RESULT AND DISCUSSION}

Table 1. uterine weight post treatment

\begin{tabular}{lcccc}
\hline & $\begin{array}{c}\text { K1 (12) } \\
\text { Rerata } \pm \text { SD }\end{array}$ & $\begin{array}{c}\text { K2 (9) } \\
\text { Rerata } \pm \text { SD }\end{array}$ & $\begin{array}{c}\text { K4 (8) } \\
\text { Rerata } \pm \text { SD }\end{array}$ & $\begin{array}{c}\text { Uji } \\
\text { komparasi } \\
\text { (value p) }\end{array}$ \\
\hline BB (pre) & $20,05 \pm 3,251$ & $21,89 \pm 5,159$ & $23,13 \pm 2,642$ & \\
BB & $24,75 \pm 3,166$ & $24,75 \pm 3,801$ & $22,75 \pm 1,581$ & 0,210 \\
(post) & 0,002 & 0,084 & 0,549 & \\
(Nilai p) & & & & \\
Delta & $4,50 \pm 2,195$ & $3,33 \pm 5,074$ & $0,38 \pm 1,685$ & 0,023 \\
\hline
\end{tabular}



Jendral A. Yani Street Lorong Gotong Royong 9/10 U1
Palembang South Sumatera

email jurnal: jurnalhon@univpgri-palembang.ac.id situs web: http://www.univpgri-palembang.ac.id

\section{Accredited}

SINTA 3

Table 1 shows that data uterine weight on post treatment. The results show that the mean uterine weight in control group (K1) was $0.11 \mathrm{gr}$, in the high calorie diet group (K2) ham mean of 0.19 gr and in the high calorie diet with moderate exercise group (K4) had mean of 0.14 gr. Normality test using shapiro-wilk test and homogeneity test using Levene's test which show that uterine weight data is normally distributed $(\mathrm{p}>0,05)$ and is not homogen $(\mathrm{p}<0,05)$. So the robust test was used to see the difference between groups. The results show that $p>0,051$, which means that there is no significant difference in the weight of uterine organs between groups.

Table 2. vaginal swab

\begin{tabular}{|c|c|c|c|c|c|c|}
\hline \multirow[t]{2}{*}{ Groups } & \multirow[t]{2}{*}{$\mathrm{N}$} & \multicolumn{4}{|c|}{ Presentase (\%) vaginal swab } & \multirow{2}{*}{$\begin{array}{c}\text { Comparation } \\
\text { test } \\
\text { (nilai p) }\end{array}$} \\
\hline & & Proestrus & Estrus & Diestrus & Metestrus & \\
\hline K1 & 7 & $42,9 \%$ & $0 \%$ & $57,1 \%$ & $0 \%$ & \\
\hline $\mathrm{K} 2$ & 5 & $0.0 \%$ & $20 \%$ & $60 \%$ & $20 \%$ & 0,045 \\
\hline K4 & 8 & $0 \%$ & $50 \%$ & $50 \%$ & $0 \%$ & \\
\hline
\end{tabular}
between groups $(\mathrm{p}<0,045)$. Proestrus $(42,9 \%)$ was most commonly found in the control group (K1), estrus $(50 \%)$ was most commonly found in the high calorie diet with moderate exercise group (K4), diestrus (60\%) was most commonly found in the high calorie diet group (K2), and metestrus (20\%) was commonly found in high calorie diet group (K2). In addition, the Fisher's Exact test showed $\mathrm{p}<0,045$, so that there were significant differences between groups.

\section{Discussion}

\section{Effect of High Calorie Diet on Reproductive Cycle}

The results of the study in the high-calorie diet group had the highest mean uterine weight $(0.19 \mathrm{~g})$. According to (Cheng et al., 2018) study the HFD (High Fat Diet) group saw an increase in the number of endometrial glands. This is due to a high-fat diet (HFD), which increases continuous estrogen activity, resulting in uterine enlargement and endometrial gland growth. 


\section{HALAMAN Jendral A. Yani Street Lorong Gotong Royong 9/10 Ulu OLAHRAGA \\ JURALALAII KEOL DIRAQHA Palembang South Sumatera \\ Accredited \\ email jurnal: jurnalhon@univpgri-palembang.ac.id situs web: http://www.univpgri-palembang.ac.id

In this study in the high-calorie diet group (K2),the results showed that mice had $60 \%$ diestrus, $20 \%$ estrus, $20 \%$ metestrus and $0 \%$ proestrus. If it is estimated manually with a time of 4-5 days of the estrus cycle, the phase after treatment is either proestrus or estrus. However, in this study, the diestrus phase was the most common in the high-calorie diet group. This is consistent with a (Chakraborty et al., 2008) research which compared mice fed HFD and normal diet (ND) and found that the HFD group had a longer phase (diestrus 4 days in a row) and skipped the phase, or a combination of the two. There was a $70 \%$ rise in the number of cells during the diestrus phase. This increase in cell number has the potential to enhance uterine mass in induced mice.HFD causes an increase in estrogen in mice, which is produced by an increase in adipose tissue, which releases aromatase, which increases the conversion of androgens to estradiol (Jasik \& Lustig, 2008).

Furthermore, an increase in adipose tissue causes an increase in the release of insulin and leptin, which reduces levels of sex hormone binding proteins, resulting in an increase in estrogen in the blood. Progesterone levels increased in mice fed HFD. It can induce a prolongation of the estrous cycle and a reduction in reproductive function as a result of an increase in estradiol and progesterone coupled with a decrease in the LH surge (Akamine et al., 2010).

\section{Effect of High Calorie Diet with Moderate Exercise on Reproductive Cycle}

The results of this research on the high-calorie diet with moderate exercise group (K4) showed that the uterine weight was in the middle $(0.14 \mathrm{~g})$ between the negative group (K1) and the high-calorie diet group (K2). In addition, vaginal swab results showed that mice went through a $0 \%$ proestrus phase, a $50 \%$ diestrus phase, a $50 \%$ estrus phase, and a $0 \%$ metestrus phase. Swimming exercise can enhance cognitive performance in high-fat diet mice by increasing GnRH secretion, but a high-fat diet can increase hypothalamic inflammation and decrease GnRH secretion (Wang et al., 2020). 
Calorie diet with moderate exercise had no effect on the menstrual cycle and resulted in a significant decrease in estrogen and progesterone as well as a transitory increase in SHBG (Williams et al., 2010). During exercise, it can also inhibit the reproductive axis via GnRH, resulting in lower LH and FSH secretion (Uadia et al., 2017). This is consistent with research by (Saadat et al., 2016) which stated that the pool mice group had lower levels of estradiol and FSH. FSH can influence follicular cell proliferation as well as granulosa and theca cell estrogen production. Theca cells are in charge of androgen synthesis in follicles, while granulosa cells may convert androgens into estrogen, estrone, and estradiol via the P450 aromatase enzyme (N Glacier, 2011).

Therefore, to reduce excess estrogen, swimming can be done, as in this study which when given a high-calorie diet will cause excess estrogen production but inhibit it by exercise, resulting in less FSH production and lower estrogen secretion. According to the findings of this study, the number of estrus phases was $50 \%$, which corresponds to the treatment phase if estimated manually with 45 days of the mice reproductive cycle.

\section{The Differences effect of High Calorie Diet with or without moderate exercise Reproductive Cycle}

The results of this research showed no significant difference ( $p$-value $0.051>0.05)$ in uterine weight between the treatment groups with a high-calorie diet (K2) and a high-calorie diet with moderate exercise (K4). However, it should be noted that in this research, the highest mean uterine weight occurred in the high-calorie diet group (K2) compared to other groups.

This is consistent with research conducted by (Hsu et al., 2021) which stated that the HFD tissue accompanied by physical exercise showed that the proportion of vacuoles and cell sizes were smaller than the HFD group. This happens as a result of a high-fructose diet, which causes female mice's body weight and adipose tissue to increase, and adipose cell hypertrophy occurs in the target tissue (uterus). However, Moderate-exercise for four weeks, will lower the 
HALAMAN
Jendral A. Yani Street Lorong Gotong Royong 9/10 Ulu
Palembang South Sumatera OLAHRAGA JUREAL JLHIIKEOLIRIQHAN
Accredited

SINTA 3

quantity of fat in the body, therefore indirectly reducing the size and proportion of vacuoles in the target tissue.

The results of the vaginal swab showed that there was a significant difference (pvalue $0.045<0.05)$ in the reproductive cycle between groups. Research conducted by (Wang et al., 2020) states that a high-fat diet (HFD) will induce hypothalamic inflammation and inhibit GnRH secretion, while swimming can improve cognitive function in high-fat diet mice by increasing $\mathrm{GnRH}$ secretion. Calorie diet with moderate exercise had no effect on the menstrual cycle and resulted in a significant decrease in estrogen and progesterone as well as a transient increase in SHBG (Williams et al., 2010).

\section{CONCLUSION}

Moderate intensity can affect to reproductive cycle in mice with high calorie diet but no effect to weight of uterine. In order to know the underlying mechanism, for futher research is needed to determine the endometrial thickness and influence of hormones, such as FSH, LH, estrogen, progesterone.

\section{REFERENCES}

Akamine, E. H., Marçal, A. C., Camporez, J. P., Hoshida, M. S., Caperuto, L. C., Bevilacqua, E., \& Carvalho, C. R. O. (2010). Obesity induced by high-fat diet promotes insulin resistance in the ovary. Journal of Endocrinology, 206(1), 65-74. https://doi.org/10.1677/JOE-09-0461

Akin, F., Bastemir, M., Alkis, E., \& Kaptanoglu, B. (2008). Associations between sex hormone binding globulin and metabolic syndrome parameters in premenopausal obese women. Indian Journal of Medical Sciences, 62(10), 407-415. https://doi.org/10.4103/0019-5359.44020

Chakraborty, S., Sachdev, A., Salton, S. R. J., \& Chakraborty, T. R. (2008). Stereological analysis of estrogen receptor expression in the hypothalamic arcuate nucleus of ob/ob and agouti mice. Brain Research, 1217, 86-95. https://doi.org/10.1016/j.brainres.2008.04.031

Cheng, Y., Lv, Q., Xie, B., Yang, B., Shan, W., Ning, C., Li, B., Xie, L., Gu, C., Luo, X., Chen, X., \& Zhu, Q. (2018). Estrogen and high-fat diet induced 
alterations in C57BL/6 mice endometrial transcriptome profile. Endocrine Connections, 7(1), 36-46. https://doi.org/10.1530/EC-17-0315

Dars, S., Sayed, K., \& Yousufzai, Z. (2014). Relationship of menstrual irregularities to BMI and nutritional status in adolescent girls. Pakistan Journal of Medical Sciences, 30(1), 140-144. https://doi.org/10.12669/pjms.301.3949

Herawati, L., Sari, G. M., \& Irawan, R. (2020). High Glycemic Index Diet Decreases Insulin Secretion without Altering Akt and Pdx1 Expression on Pancreatic Beta Cells in Mice. Chiang Mai University Journal of Natural Sciences, 19(3), 363-375. https://doi.org/10.12982/cmujns.2020.0024

Hsu, Y. J., Lee, M. C., Huang, C. C., \& Ho, C. S. (2021). The effects of different types of aquatic exercise training interventions on a high-fructose diet-fed mice. International Journal of Medical Sciences, 18(3), 695-705. https://doi.org/10.7150/ijms.52347

Jasik, C. B., \& Lustig, R. H. (2008). Adolescent obesity and puberty: The "perfect storm." Annals of the New York Academy of Sciences, 1135, 265-279. https://doi.org/10.1196/annals.1429.009

Kemenkes RI. (2018). Hasil Riset Kesehatan Dasar Tahun 2018. Kementrian Kesehatan RI, 53(9), 1689-1699.

Kementerian Kesehatan RI. (2018). Epidemi Obesitas. In Jurnal Kesehatan (pp. 1-8). http://www.p2ptm.kemkes.go.id/dokumen-ptm/factsheet-obesitas-kitinformasi-obesitas

Prasetya, R. E., Umijati, S., \& Rejeki, P. (2018). Effect of Moderate Intensity Exercise on Body Weight and Blood Estrogen Level Ovariectomized Mice. Majalah Kedokteran Bandung, 50(3), 147-151. https://doi.org/10.15395/mkb.v50n3.1368

Saadat, S. N. S., Mohammadghasemi, F., Ebrahimi, H., Sajedi, H. R., \& Chatrnour, G. (2016). Ovarian and uterine alterations following forced swimming: An immunohistochemical study. International Journal of Reproductive BioMedicine, 14(10), 629-636. https://doi.org/10.29252/ijrm.14.10.629 
Jendral A. Yani Street Lorong Gotong Royong 9/10 Ulu Palembang South Sumatera

email jurnal: jurnalhon@univpgri-palembang.ac.id situs web: http://www.univpgri-palembang.ac.id

\section{Accredited}

SINTA 3

Sunarsih. (2017). Hubungan Status Gizi dan Aktifitas Fisik Terhadap Keteraturan Siklus Menstruasi Mahasiswa Program Studi Kebidanan Universitas Malahayati Tahun 2017. Jurnal Kebidanan, 3(4), 190-195. http://ejurnalmalahayati.ac.id/

Uadia, P. O., Nwokolo, C. C., Orumwensodia, K. O., Arainru, G. E., Agwubike, E. O., \& Akpata, C. B. N. (2017). Effect of physical and flexibility exercise on certain hormones and fasting blood sugar of some young Nigerian adults. Tropical Journal of Pharmaceutical Research, 16(1), 245-250. https://doi.org/10.4314/tjpr.v16i1.33

Wang, X., Yang, J., Lu, T., Zhan, Z., Wei, W., Lyu, X., Jiang, Y., \& Xue, X. (2020). The effect of swimming exercise and diet on the hypothalamic inflammation of ApoE-/- mice based on SIRT1-NF-kB-GnRH expression. Aging, 12(11), 11085-11099. https://doi.org/10.18632/aging.103323

Williams, N. I., Reed, J. L., Leidy, H. J., Legro, R. S., \& De Souza, M. J. (2010). Estrogen and progesterone exposure is reduced in response to energy deficiency in women aged 25-40 years. Human Reproduction, 25(9), 23282339. https://doi.org/10.1093/humrep/deq172

Yang, Y. J. (2019). An Overview of Current Physical Activity Recommendations in Primary Care. Korean Journal of Family Medicine, 40(3), 135-142. https://doi.org/10.4082/kjfm.19.0038

Yuli Trisnawati, T. A. (2018). Korelasi Indeks Masa Tubuh dengan Siklus Menstruasi pada Mahasiswa Akademi Kebidanan YLPP Purwokerto. Jurnal Publikasi Kebidanan, 9(1), 21-30. 